\title{
At the crossroads: Hazard assessment and reduction of health risks from arsenic in private well waters of the northeastern United States and Atlantic Canada
}

\author{
Yan Zheng a,b,*,1, Joseph D. Ayotte ${ }^{c, 1}$ \\ a City University of New York, School of Public Health and Queens College, City University of New York, 65-30 Kissena Blvd., Flushing, NY 11367, United States of America \\ b Columbia University, Lamont-Doherty Earth Observatory, 61 Route 9, Palisades, NY 10964, United States of America \\ c U.S. Geological Survey, 331 Commerce Way, Pembroke, NH 03301, United States of America
}

\section{H I G H L I G H T S}

- The health risks from arsenic in private well water are overlooked.

- Arsenic hazard assessment is necessary but does not reduce exposure.

- New understanding of impediments to well users' testing and mitigating is helpful.

- In addition to treatment, alternative water supply can reduce arsenic exposure.

- Additional public resources could assist with arsenic exposure reduction.

\section{A R T I C L E I N F O}

\section{Article history:}

Received 25 October 2014

Accepted 25 October 2014

Available online 18 November 2014

Editor: D. Barcelo

\section{Keywords:}

Arsenic

Private well water

Hydrogeology

Geochemistry

Behavior

Exposure reduction

\begin{abstract}
A B S T R A C T
This special issue contains 12 papers that report on new understanding of arsenic (As) hydrogeochemistry, performance of household well water treatment systems, and testing and treatment behaviors of well users in several states of the northeastern region of the United States and Nova Scotia, Canada. The responsibility to ensure water safety of private wells falls on well owners. In the U.S., 43 million Americans, mostly from rural areas, use private wells. In order to reduce As exposure in rural populations that rely on private wells for drinking water, risk assessment, which includes estimation of population at risk of exposure to As above the EPA Maximum Contaminant Level, is helpful but insufficient because it does not identify individual households at risk. Persistent optimistic bias among well owners against testing and barriers such as cost of treatment mean that a large percentage of the population will not act to reduce their exposure to harmful substances such as As. If households are in areas with known As occurrence, a potentially large percentage of well owners will remain unaware of their exposure. To ensure that everyone, including vulnerable populations such as low income families with children and pregnant women, is not exposed to arsenic in their drinking water, alternative action will be required and warrants further research.
\end{abstract}

C 2014 Elsevier B.V. All rights reserved.

\section{Introduction}

Exposure to geogenic arsenic (As) in groundwater, the dominant source of drinking water for rural populations that rely on private wells, has been recognized as a widespread global public health concern (Ravenscroft et al., 2009). In the U.S., testing for As in private well water

\footnotetext{
* Corresponding author. Tel.:+1 718997 3300; fax:+1 7189973299.

E-mail addresses: yan.zheng@qc.cuny.edu, yzheng@ldeo.columbia.edu (Y. Zheng), jayotte@usgs.gov (J.D. Ayotte).

${ }^{1}$ Guest editors of the special issue.
}

is the responsibility of the well owner because there is essentially no regulation of the quality of the well water, as there is for public drinking water supplies, which are regulated under the Safe Drinking Water Act. It is estimated that there are over 13 million private wells in the U.S. (Hutcheson et al., 1995), and that about 15\% of the U.S. population, or over 43 million people, rely on private wells for their drinking water (Hutson et al., 2004). To what extent households in the U.S. have tested their private wells for water quality, including As, and have employed a household water treatment method to ensure drinking water safety if necessary, has not been evaluated systematically (DeSimone et al., 2009). This is a public health concern because there is widespread 
groundwater As occurrence in several regions of the U.S. (Ryker, 2001), including the northeastern United States (Ayotte et al., 2003; Flanagan et al., 2012) and the adjoining Atlantic Canadian provinces (Grantham and Jones, 1977). The U.S. Geological Survey National Water-Quality Assessment Program, through testing of 1774 private wells from 48 states representing 30 of the 62 principal aquifers of the United States, has reported that $6.8 \%$ of the samples contain concentrations of As $>10 \mu \mathrm{g} / \mathrm{L}$, the EPA's maximum contaminant level (MCL), and that more than $10 \%$ of wells contain concentrations of As $>10 \mu \mathrm{g} / \mathrm{L}$ in crystalline-bedrock aquifers in New England, basin-fill aquifers in the western and south-central U.S., and a basaltic-rock aquifer in Idaho (DeSimone et al., 2009). Testing of individual private well water for As is the only way to determine the concentration of As in the water and to assess whether the water is safe to consume. This is because spatial distribution of groundwater As is highly variable at local and regional scales (Peters et al., 1999; Yang et al., 2009), and risk assessment models do not currently have the capability to predict As level for individual wells (Ayotte et al., 2006; Yang et al., 2012).

In response to the EPA's request to update the toxicological assessment of inorganic As to include cancer and non-cancer effects, the National Research Council convened a committee on inorganic As in 2012. An interim report released on Nov. 7, 2013 (NRC, 2013), reviews expanded epidemiologic studies of the associations between exposure to As in drinking water and a variety of adverse health outcomes, including cardiovascular disease, diabetes, neoplastic respiratory changes, skin lesions, pregnancy outcomes, child development, skin cancers, bladder cancers, and lung cancers. The report notes that the studies increasingly characterize risks at low to moderate As exposure (10 to 100 $\mu \mathrm{g} / \mathrm{L}$ As). Recognizing that extrapolations in the EPA process of quantitative dose-response analysis are among the most controversial aspects of As risk assessment, the committee recommends that health effects from early-life exposure be considered in the dose-response assessment because early-life exposure to As, even at low concentrations, increases the risk of adverse health effects and impairs development in infancy, childhood and later in life. Susceptibility due to pre-existing disease is also an important consideration because As has been shown to increase the risk of several major diseases prevalent in the United States (e.g., diabetes, cardiovascular diseases). Because adverse health effects of inorganic As are likely to be greater for susceptible groups than for the general population, reduction to As exposure in the U.S. population will require simultaneously identifying households with elevated well-water As and vulnerable groups, such as pregnant women, families with young children, and perhaps persons with diabetes and cardiovascular diseases.

When it comes to the reduction of exposure to As through drinking private well water in the U.S. to prevent adverse health outcomes, we are at a crossroads. Since the 1990s, hydrogeochemical and biomedical research has greatly improved our understandings of factors influencing groundwater As occurrence at regional spatial scales and adverse health impacts for vulnerable populations at low to moderate doses. However, little is known about what actions households with private wells may have taken to reduce exposure to As in their drinking water and the reasons for taking such actions (Severtson et al., 2006; Shaw et al., 2005). There are also many issues with the performance of household As treatment units in real-world situations, one of which is failure of household reverse-osmosis systems when levels of As in raw well waters are high and dominated by trivalent As(III) (Walker et al., 2008). Efforts to promote As testing and treatment can benefit from closing these knowledge gaps. Therefore, this special issue "Arsenic in private well waters of the northeastern United States and Atlantic Canada" includes not only articles that further investigate hydrogeological and biogeochemical characteristics of As-rich groundwater in the northeastern North America (Section 2), but also articles that explore the behaviors of households in response to elevated As in private well water (Section 3). We conclude with a discussion of possible solutions to reduce As exposure from drinking water in private wells (Section 4).

\section{Risks from arsenic in private well water of Northeast United States}

Ayotte (in press) reviewed the arsenic hazard in groundwater and associated health risks in 6 states of New England, United States. Arsenic was first identified in New England groundwater in the 1980s (Boudette et al., 1985; Zuena and Keane, 1985) and in Nova Scotia groundwater in the 1970s (Grantham and Jones, 1977). A key research finding is the association between occurrence of elevated concentrations of As in groundwater and the geology of the eastern New England region (Ayotte et al., 1999, 2003; Peters et al., 1999). This finding was aided by an alternative characterization of the geologic formations that reclassifies the bedrock geologic formations into "lithogeochemical" units (Robinson and Kapo, 2003). The reclassified "calcareous metasedimentary rock units" host bedrock aquifers where well waters frequently contain elevated concentrations of As (As $>10 \mu \mathrm{g} / \mathrm{L}$ ) in a band throughout central Maine, southern New Hampshire, central Massachusetts and Connecticut (Ayotte et al., 1999, 2003; Colman, 2011; Moore, 2004; Peters and Blum, 2003; Peters et al., 1999; Yang et al., 2009). In such aquifers, which are common in eastern New England (Fig. 1), about $40 \%$ of groundwater samples characterized by $\mathrm{pH}>7$ and very little dissolved oxygen $(<1 \mathrm{mg} / \mathrm{L})$ were found to contain $>10 \mu \mathrm{g} / \mathrm{L}$ of As, compared to less than $10 \%$ of groundwater samples that are characterized by acidic and oxic chemistry (Ayotte, in press). Furthermore, Ayotte et al. (2003) determined that over 100,000 people in this region are likely to have wells with arsenic $>10 \mu \mathrm{g} / \mathrm{L}$, but this number may be low because more recent testing has revealed higher occurrence rates of As in some parts of the region (Flanagan et al., 2012).

Hydrogeological and biogeochemical studies of aquifers in the neighboring Canadian provinces of New Brunswick and Nova Scotia, as well as in Vermont and the Newark Basin of New Jersey and Pennsylvania in the United States, have added to the understanding of lithogeochemical control of As occurrence in a broader northeast North American region (Table 1). In Nova Scotia, samples from 642 wells in various gold mine districts indicate that $13 \%$ of wells contained $>50 \mu \mathrm{g} / \mathrm{L}$ of As, compared to $12 \%$ of wells with $>50 \mu \mathrm{g} / \mathrm{L}$ of As determined from 183 samples from non-gold mine districts (Grantham and Jones, 1977), suggesting that As in groundwater is not limited to gold mine districts. The study was motivated by the discovery of a human arsenic poisoning case from exposure to $\sim 5000 \mu \mathrm{g} / \mathrm{L}$ of As in well water in the Waverley area of Halifax County in February, 1976. Subsequently, a survey of 94 wells in communities nearby found that $23 \%$ of wells contained $>250 \mu \mathrm{g} / \mathrm{L}$ of As, and only 5 samples had $<10$ $\mu \mathrm{g} / \mathrm{L}$ of As (Meranger et al., 1984). Although gold mining can be a source of As pollution of surface water and stream sediments, most of the wells with elevated As concentrations in southern Nova Scotia are located in the fractured slate, greywacke and quartzite of the Halifax and Goldenville Groups of the marine-deposited Cambrian-Lower Ordovician Meguma Supergroup (Bottomley, 1984) with the presence of arsenic-rich pyrite (Brooks et al., 1982). The four wells in the Meguma Supergroup with groundwater As concentrations ranging from 18 to $365 \mu \mathrm{g} / \mathrm{L}$ have $\mathrm{pH}$ values greater than 7 and tend to be low in dissolved oxygen, with $>90 \%$ of the As present as As(III) (Bottomley, 1984). In this special issue, a study of spatial patterns of well water As in Nova Scotia has led to the development of a statistical model based on arsenic concentrations in 10,498 private wells that predicted not only concentrations of arsenic in well water from a set of geological and environmental factors but also concentrations of arsenic in toenail samples from study subjects (Dummer et al., 2015-in this issue). The maximum As concentration from the 10,498 private wells in Nova Scotia was $3900 \mu \mathrm{g} / \mathrm{L}$, with $17 \%$ of the wells containing more than $10 \mu \mathrm{g} / \mathrm{L}$ of As (Table 2). This large dataset unequivocally demonstrates that the highest As levels in groundwater are associated with the sulfide or gold-bearing meta-sedimentary rocks of the Meguma Supergroup (Table 1).

In Bennington and Rutland counties of southwestern Vermont (Fig. 1), 28\% (50/176) of low-elevation wells ( $<245 \mathrm{~m}$ above sea level 


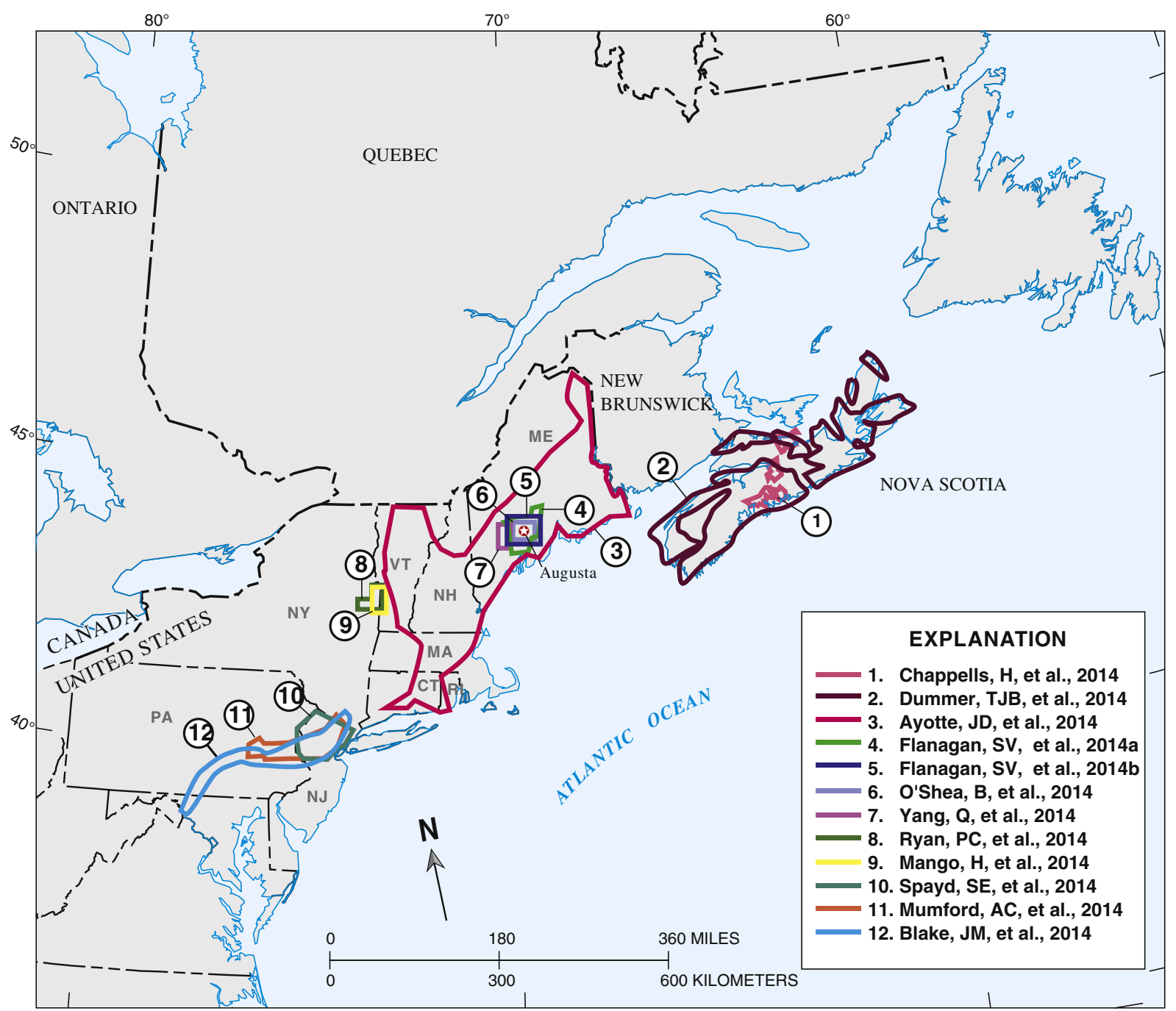

Base from U.S. Geological Survey coordinate system Clarke 1866,

Hotine Oblique Mercator Azimuth Natural Origin

Projection: Hotine Oblique Mercator Azimuth Natural Origin

Datum is Clarke 1866, Scale: 1,0000

Fig. 1. Locations of 12 studies published in the special issue are labeled, with the approximate geographic extent outlined in color.

[masl]) exceed $10 \mu \mathrm{g} / \mathrm{L}$ of As, whereas only 3\% (2/60) of higher-elevation wells (245-600 masl) exceed $10 \mu \mathrm{g} / \mathrm{L}$ of As in a slate aquifer with presence of arsenian pyrite (200-2000 mg/kg As) (Ryan et al., 2013). Additionally, geochemically reducing and slightly alkaline conditions $(\mathrm{pH}>7)$ are associated with high As values (Table 1). In north-central Vermont, phyllite (metamorphosed shales and sandstones) and greenstone (metabasalt), but especially serpentinite and associated ultramafic rocks with an average As concentration of $93 \mathrm{mg} / \mathrm{kg}$, are suspected to be sources of As to groundwater because nearly all wells with As $>10 \mu \mathrm{g} / \mathrm{L}$ are within $5 \mathrm{~km}$ of ultramafic outcrops (Ryan et al., 2011).

In the Newark Basin in New Jersey and Pennsylvania, groundwater As occurs in Mesozoic sedimentary strata composed of sandstone and red mudstone with inter-bedded gray shale and gray to black siltstone and shale but not in diabase intrusions (Peters and Burkert, 2008; Serfes et al., 2005). In the Piedmont regions of the Newark Basin, 23\% of 53 wells sampled in Pennsylvania (Peters and Burkert, 2008) and $15 \%$ of 94 wells sampled in New Jersey (Serfes et al., 2005) contained high $(>10 \mu \mathrm{g} / \mathrm{L})$ concentrations of As. A dataset of 12,263 private wells tested for As between September 2002 and April 2007 through New Jersey's Private Well Testing Act Program identified 12\% of tested wells as exceeding the New Jersey MCL of $5 \mu \mathrm{g} / \mathrm{L}$ but over $40 \%$ of wells as exceeding $5 \mu \mathrm{g} / \mathrm{L}$ in certain Piedmont regions (Spayd et al., 2015-in this issue). The red, gray, and black mudstone and shale of Newark Basin contained As concentrations of as much as 13, 50, and $240 \mathrm{mg} /$ $\mathrm{kg}$, respectively, with pyrite $\left(\mathrm{FeS}_{2}\right)$ in the black shale containing up to $40,000 \mathrm{mg} / \mathrm{kg}$ of As (Serfes et al., 2005). Well waters in New Jersey and Pennsylvania, like those in New England, with $\mathrm{pH}$ values that are near or above 7 tend to contain elevated As, i.e., $\mathrm{pH}>6.4$ in Pennsylvania (Peters and Burkert, 2008) and $\mathrm{pH}>7.5$ in New Jersey (Table 1). Water chemistry data from 5023 groundwater samples collected from monitoring, domestic, public supply, commercial, irrigation, and industrial wells between 1997 and 2007 in Pennsylvania show that the glacial aquifer in the central lowland province in northwest Pennsylvania also has high rates (20\%) of samples with $>10 \mu \mathrm{g} / \mathrm{L}$ of As (max As $293 \mu \mathrm{g} / \mathrm{L}$ ), as do the Newark and Gettysburg Basins (Gross and Low, 2013). Overall, a larger percentage of anoxic and high-pH waters contain elevated concentrations of As than low-pH oxic groundwater does. Sediment pore waters collected from streambeds of Six Mile Run and Pike Run (tributaries to the Millstone River in the New Jersey Piedmont Physiographic Province) had distinctly different redox conditions and microbial communities at the low and high As sites, suggesting that certain microbes may promote geogenic As mobilization 
Table 1

Table $\mathbf{1}$
Geological and hydrogeochemical characteristics of bedrock aquifers containing arsenic.

Province/state Geologic formations (Fms) Rock

Rock

Hydrochemistry

Groundwater

n Max As

$\mathrm{mg} / \mathrm{kg}$

$\begin{array}{ll}\operatorname{Max} & \% \\ \text { As } & >10 \mu \mathrm{g} / \mathrm{L} \\ \mu \mathrm{g} / \mathrm{L} & \text { As }\end{array}$

Nova Scotia

Meta-sedimentary rocks (slates, greywackes and quartzites) of the Halifax and

$55>1000$

Goldenville groups of the marine-deposited Cambrian-Lower Ordovician

Meguma Supergroup, regionally metamorphosed to the greenschist facies

during the Devonian period. Arsenic as arsenian pyrite in quartz veins once

mined for gold. The 95th percentile [As] in well water in each of the five

bedrock regions are: metamorphic $(65 \mu \mathrm{g} / \mathrm{L})$, plutonic $(34 \mu \mathrm{g} / \mathrm{L})$, sedimentary

$(10 \mu \mathrm{g} / \mathrm{L})$, carbonate/evaporite $(9.0 \mu \mathrm{g} / \mathrm{L})$, and volcanic region $(3.0 \mu \mathrm{g} / \mathrm{L})$

Maine Ordovician Penobscot Fm with sulfidic, carbonaceous, thinly bedded,

Maine

New Brunswick Harvey Fm with volcanic tuff overlain by thick deposits of Carboniferous

sandstone and other clastic rocks. Magnetite contains As. As risk ranks from

high in black shale, coal, high-Fe sedimentary rock, moderate and moderate-

low in extrusive igneous and marine sedimentary rocks, to low in intrusive

igneous and non-marine sedimentary rocks

alternating schist and quartzite with rare limestone and calcareous sandstone

(

and a diorite porphyry. Pyrites from sulphidic bedrock contain 436-1290 m
$\mathrm{kg}$ of As.

Five Fms of the Central Maine terrane displayed high to low groundwater 39\%), SOv (Vassalboro, 24\%), D (Devonian granite intrusions, 15\%) and OZc $39 \%$ ), SOv (Vassalboro, 24\%), D (Devonian granite intrusions, 15\%) and OZc
(Ordovician-Cambrian volcanic rocks of Cushing Fm, 9\%). Three meta-

(Ordovician-Cambrian volcanic rocks of Cushing Fm, 9\%). Three meta-
sedimentary Fms (Ss, Sw, SOv) were Silurian interbedded calcareous pelite and sandstone, some with limestone or calc-silicates. Pyrites contain up to

$1944 \mathrm{mg} / \mathrm{kg}$ of As, averaging $706 \pm 451 \mathrm{mg} / \mathrm{kg}(\mathrm{n}=115)$.

New Hampshire Part of the Central Maine terrane consisted of meta-sedimentary rocks of the

Silurian Rangeley Fm (calcareous metapelites) and the Littleton Fm intruded by

the NH Plutonic Series (Kinsman, Bethlehem and Spaulding) in early Devonian.

Partial melting of the Rangeley and Littleton Fms led to the emplacement of

Concord Granites. During the late stages of emplacement, pegmatites and

graphite-containing veins formed from metamorphism and melting of the

Rangeley Fm, enriching the incompatible elements including As. As-bearing

minerals include arsenopyrite (FeAsS) and its alteration products

nanocrystalline magnetite and westerveldite.
Elevated [As] are more frequently observed in samples with high $\mathrm{pH}$, low DO, and low nitrate. Median $[\mathrm{Fe}]=0.11 \mathrm{mg} / \mathrm{L}$

$1113 \quad 325$

High As ( $>38 \mu \mathrm{g} / \mathrm{L}$ ) water has low Fe $(<0.8 \mathrm{mg} / \mathrm{L})$, variable $\mathrm{DO}, \mathrm{pH} 7-8$, variable $\mathrm{pE}, 0 \%-100 \%$ As as AsIII
Lipfert (2006); Lipfert et

(2008)

Yang et al. (2009); Yang et al. (2012); Yang et al. (2015-in (2015-in and 2015-in this issue)

Peters and Blum (2003); Peters et al. (2006); Utsunomiya et al. (2003) 

to black slate interlayered with limestone and quartzite (mid-Cambrian West Castleton/Hatch Hill Fms), to the gray, green and purple slate and phyllite (Bull/Metawee Fm). Arsenic in pyrite ranged from 53 to $2075 \mathrm{mg} / \mathrm{kg}$.

Vermont In N Vermont, meta-sedimentary rocks, phyllites (Proterozoic-to-Cambrian Hazens Notch and Stowe Fms, the Cambrian Ottauqueechee Fm and the lateCambrian to Ordovician Moretown Fm); originated as marine sediments, then were incorporated into an accretionary prism and subsequently

metamorphosed. These rocks now occur in fault contact with each other and with the serpentinized ultramafics. Metamorphosed basaltic volcanic rocks occur as greenstones and amphibolites along faults. As is located in antigorite and magnesite with lesser amounts in magnetite.

Massachusetts In central MA, probability of As occurrence is high in Neoproterozoic

amphibolite-biotite gneiss (Boxford member of the Nashoba Formation 26\% Marlboro Formation 11\%, Fish Brook Gneiss 8\%), moderate in Silurian plutons Marlboro Formation 11\%, Fish Brook Gneiss 8\%), moderate in Silurian plutons
(Andover Granite granite 7\%, Sharpners Pond Diorite 5\%) and phyllite-schist (Andover Granite granite 7\%, Sharpners Pond Diorite 5\%) and phyllite-schist
(Tadmuck Brook Schist 4\%), low in Neoproterozoic schist-gneiss (Nashoba (Tadmuck Brook Schist 4\%), low in Neoproterozoic schist-gneiss (Nashoba)
Formation $<1$ ) and Silurian schist (parts of the Paxton Formation $<1 \%$. Formation $<1$ ) and Silurian schist (parts of the Paxton Formation < $1 \%$ ).
Pyrites $\left(\mathrm{FeS}_{2}\right.$ ) contain negligible amounts of As, however, As levels in cobaltite (CoAsS) range from 30 to $50 \%$ of As by weight.

Connecticut In northeastern CT (Woodstock), a biotite schist of Hebron Fm intruded by numerous pegmatitic and granitic sills and dikes

Rhode Island

New Jersey

in NW New Jersey and SE Pennsylvania, the Piedmont Province of the Newark Basin has sedimentary sequences (Upper Triassic and Lower Jurassic 195-

225 M.A.) with sandstone, black and red mudstone, siltstone and pyrite-

containing shale (Lockatong Fm), and red mudstone and siltstone interlayered with black shale (Passaic Fm) intruded by a diabase. Pyrite in the black shale contains up to $40,000 \mathrm{mg} / \mathrm{kg}$ As

Pennsylvania In NW Pennsylvania, the glacial aquifer emerged as the third area in the state (2015-in this issue); Mango and Ryan (2015-in this issue)

107449 (serpentine); $1105 \quad \mathrm{Mg}-\mathrm{HCO}_{3}$ type, $\mathrm{pH}$ 7.4-7.6, three wells (talc-magnesite); 189 sampled were located in recharge zone (talc-chlorite); 190

(meta-sed); 69

(meta-basalt)

Ryan et al. (2011)

CaMg- $\mathrm{HCO}_{3}$ type, $\mathrm{pH} 7.7-8.3$, variable DO, low Fe $(<0.01-0.17 \mathrm{mg} / \mathrm{L})$

240

Low DO $<3 \mathrm{mg} / \mathrm{L}, \mathrm{pH} 7.5-8.2$

pH 6.4-7.5, variable Eh, $>70 \%$ samples mostly $\mathrm{As}(\mathrm{V})$, low $\mathrm{Fe}<0.22 \mathrm{mg} / \mathrm{l}$, low nitrate $<400 \mu \mathrm{M}$

Alkalinity, $\mathrm{pH}$, sulfate, and TOC were positively correlated $w / A s$. DO and

nitrate plus nitrite were negatively correlated
$13 \quad 478 \quad 1540 \quad$ Colman (2011)

Brown and Chute (2002)

$94 \quad 215 \quad 15 \quad$ Serfes et al. (2005)

$\begin{array}{llll}53 & 72 & 23 & \text { Peters and Burkert (2008) }\end{array}$

\footnotetext{
a Excluded 4 tourmaline vein samples, one of which has $1050 \mathrm{mg} / \mathrm{kg}$ As.

Excluded 59 mine samples (max As 10,000 mg/kg), 21 vein samples (max As $622 \mathrm{mg} / \mathrm{kg}$ ), and 15 samples with graphite (max As $622 \mathrm{mg} / \mathrm{kg}$ ).
}

c Excluded 14 samples with pyrite cubes (max As 1,050 mg/kg) and 2 samples with $\mathrm{FeOOH}$ (max As $189 \mathrm{mg} / \mathrm{kg}$ ). 
Local government regulations on testing for arsenic in private well water and occurrence rate at state level. Row "New Hampshire" Columb \%>10 ug/L As: Move 17.2 one line down so instead of 12/17.2 it appears as 12/17.2.

\begin{tabular}{|c|c|c|c|c|c|c|c|}
\hline \multirow[t]{2}{*}{ Province/state } & \multirow[t]{2}{*}{ Regulations } & \multirow[t]{2}{*}{ Content of regulations or recommendations } & \multirow{2}{*}{$\begin{array}{l}\text { Outreach Brochure } \\
\text { pages }\end{array}$} & \multicolumn{2}{|c|}{ Private well As } & \multirow{2}{*}{$\begin{array}{l}\text { Max As } \\
\mu \mathrm{g} / \mathrm{L}\end{array}$} & \multirow[t]{2}{*}{ References } \\
\hline & & & & $\mathrm{N}$ & $\begin{array}{l}\%>10 \mu \mathrm{g} / \mathrm{L} \\
\text { As }\end{array}$ & & \\
\hline Nova Scotia & None & $\begin{array}{l}\text { Private well owners are responsible for ensuring that their wells are constructed to provincial standards } \\
\text { and for testing their water regularly. The chemical quality should be checked every } 1 \text { to } 2 \text { years. } \\
\text { Approximately } 46 \% \text { of Nova Scotians use private wells. }\end{array}$ & 16 & 10,498 & 17 & 3900 & $\begin{array}{l}\text { Dummer et al. } \\
\text { (2015-in this issue) }\end{array}$ \\
\hline New Brunswick & $\begin{array}{l}\text { Potable Water Regulation of the } \\
\text { Clean Water Act (NB Reg 93-203) }\end{array}$ & $\begin{array}{l}\text { When a contractor drills, deepens or repairs a well, a testing voucher that covers the cost of inorganic } \\
\text { and microbiological analysis is provided to the home owner, as required by NB Reg } 93-203 \text {. Use of the } \\
\text { voucher is encouraged within } 1 \text { year. Inorganic analyses are recommended every } 2 \text { to } 3 \text { years or more } \\
\text { often. Approximately } 64 \% \text { of the population uses well water. }\end{array}$ & 3 & 10,555 & 6 & 850 & Klassen et al. (2009) \\
\hline Maine $^{\mathrm{a}}$ & $\begin{array}{l}\text { None. The 123rd legislature } \\
\text { proposed an act to ensure safe } \\
\text { drinking water from private wells } \\
\text { (HP1242, LD 1775), failed to pass } \\
\text { on May 22, 2007 }\end{array}$ & $\begin{array}{l}\text { Well owners are encouraged to test their water for all items on the Well Testing Schedule every } 3 \text { to } \\
5 \text { years. Approximately } 42 \% \text { of the population uses private well water. }\end{array}$ & 4 & 11,111 & 18.4 & 3100 & Nielsen et al. (2010) \\
\hline New Hampshire ${ }^{\mathrm{b}}$ & $\begin{array}{l}\text { None. Chapter } 485 \text { New } \\
\text { Hampshire Safe Drinking Water } \\
\text { Act Section } 485 \text { has a clause on } \\
\text { private water sources }\end{array}$ & $\begin{array}{l}\text { Section } 485: 33 \text { Analyses; Prohibiting Use: whenever any well, spring or other water supply is } \\
\text { suspected of being polluted by sewage or other matter dangerous to health, the health officer of the } \\
\text { town where it is located may require an analysis of the water to be made by a competent chemist, } \\
\text { without expense to the owner. If the analysis shows the water to be unfit for drinking purposes they } \\
\text { may, with the approval of the department, prohibit its use, and, if from a well, may cause the well to be } \\
\text { closed. Prospective home-buyers are encouraged to test well water. Test intervals can be of } 3 \text { to } 5 \text { years. } \\
\text { Approximately } 46 \% \text { of the population uses private well water. }\end{array}$ & 2 & $\begin{array}{l}794 / \\
232\end{array}$ & $12 / 17.2$ & $\begin{array}{l}180 / \\
140\end{array}$ & $\begin{array}{l}\text { Peters et al. (2006); } \\
\text { Flanagan et al. } \\
\text { (2014) }\end{array}$ \\
\hline Vermont & $\begin{array}{l}\text { S. } 77 \text { An act relating to water } \\
\text { testing of private wells effective } \\
\text { Jan } 1,2012\end{array}$ & $\begin{array}{l}\text { Requires a private well for use as a potable water supply to be tested for drinking water contaminants } \\
\text { when the well is initially drilled and as a condition of a contract for sale. Requires the Agency of Natural } \\
\text { Resources to develop a well testing kit for As, Pb, U, gross alpha, coliform bacteria that would be } \\
\text { available to the public at a cost of }<\$ 120 \text {. Requires the department of health to revise and update its } \\
\text { education and outreach materials regarding the potential health effects of contaminants in private } \\
\text { sources of drinking water. Approximately } 37 \% \text { of the population uses private well water. }\end{array}$ & Not available & 236 & 22 & 170 & Ryan et al. (2013) \\
\hline Massachusetts & None & $\begin{array}{l}\text { Prospective homebuyers are required to test the well water before purchase. Test initially for all } \\
\text { contaminants including As, then at a minimum of once every } 10 \text { years except for yearly bacteria and } \\
\text { nitrate/nitrite monitoring, or as otherwise required by the local Board of Health. Approximately } 8 \% \text { of } \\
\text { the population uses private well water. }\end{array}$ & 2 & 344 & 13 & 1540 & Colman (2011) \\
\hline Rhode Island & $\begin{array}{l}\text { Rules and regulations pertaining } \\
\text { to private drinking water systems } \\
\text { (R-23-1-5.3-PDW) June } 2008\end{array}$ & $\begin{array}{l}\text { All private wells subject to a minimum testing requirement for } 17 \text { constituents, but not for As. } \\
\text { Approximately } 11 \% \text { of the population uses private well water. }\end{array}$ & 2 & & & & \\
\hline Connecticut & $\begin{array}{l}\text { None. Proposed Private Well } \\
\text { Water Testing Act abandoned in } \\
1997\end{array}$ & $\begin{array}{l}\text { Whereas most areas of Connecticut may have little or no As present in groundwater, testing at least } \\
\text { once for As is recommended. Approximately } 22 \% \text { of the population uses private well water. }\end{array}$ & 2 & & & & \\
\hline New Jersey & $\begin{array}{l}\text { Private Well Testing Act (N.J.S.A. } \\
\text { 58:12A-26 et seq) and regulations } \\
\text { (N.J.A.C. 7:9E et seq.) effective } \\
2001\end{array}$ & $\begin{array}{l}\text { All contracts of sale for any real property with a private well, or for any other real property that has a } \\
\text { well that does not regularly serve } 25 \text { individuals daily at least } 60 \text { days out of the year, shall include a } \\
\text { provision requiring, as a condition of the sale, the testing of that water supply for certain parameters } \\
\text { including As for Bergen, Essex, Hudson, Hunterdon, Mercer, Middlesex, Morris, Passaic, Somerset, } \\
\text { Sussex, Union, and Warren County locations. Approximately } 10 \% \text { of the population uses private well } \\
\text { water. }\end{array}$ & 14 & 31,033 & 3.1 & 400 & $\begin{array}{l}\text { NJDEP data Sept } \\
\text { 2012, unpublished; } \\
\text { Spayd et al. (2015- } \\
\text { in this issue) }\end{array}$ \\
\hline Pennsylvania $^{c}$ & $\begin{array}{l}\text { None statewide. Under Local } \\
\text { Health Administration Law Act } \\
\text { No. 315, Bucks County Dept of } \\
\text { Health (BCDH) Rules and } \\
\text { Regulations Governing All wells } \\
\text { and Their Construction } \\
\text { Specifications Effective Jan } 2011 .\end{array}$ & $\begin{array}{l}\text { Pennsylvania Department of Environmental Protection (PA DEP) recommends testing well water } \\
\text { periodically without mentioning As specifically. In Bucks County, water analysis of the completed new } \\
\text { well must be submitted to the BCDH within } 60 \text { days and includes As. If any well water parameter tested } \\
\text { for a new well exceeds the MCA established by PA DEP, treatment shall be required. Approximately } 20 \% \\
\text { of population uses private well water. }\end{array}$ & Not available & 4620 & 27 & 83 & $\begin{array}{l}\text { Peters and Burkert } \\
(2008)\end{array}$ \\
\hline
\end{tabular}

a Studies in Buxton (Marvinney et al., 1994) and Greater Augusta areas (Yang et al., 2009, Table 1) found higher As occurrence rates than state wide data.

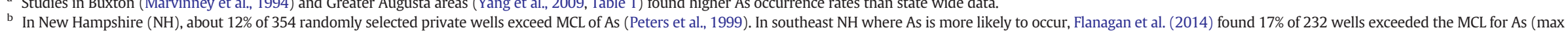
$140 \mu \mathrm{g} / \mathrm{L})$.

c A subset of Pennsylvania private wells in geologic formations (Passaic, Lockatong, Diabase, Pre-Cambrian/Cambrian, Table 3 in Peters and Burkert, 2008) with known As occurrence. 
under reducing conditions, whereas others do not (Mumford et al., 2015-in this issue).

Drawing on some of the aforementioned studies, a review of As in groundwater in the Northern Appalachian Mountain belt highlighted the spatially heterogeneous groundwater As patterns and the $\mathrm{pH}-$ dependent desorption reactions in mobilizing As from amorphous iron minerals-the oxidized products of naturally occurring arsenic-rich pyrite in the bedrock (Peters, 2008). Peters (2008) also proposed a tectonic framework that links the high As region in the Northern Appalachian Mountain belt to crustal recycling of As as an incompatible element during accretion of multiple terranes, especially the Avalonian and the Central Maine Terrane.

In this special issue, advances in understanding of the lithogeochemistry and mineralogy of such bedrocks are made. For example, arsenic is present at concentrations of up to $138 \mathrm{mg} / \mathrm{kg}$ in meta-sedimentary rocks of two adjacent formations in central Maine (O'Shea et al., 2015-in this issue), where about $40 \%$ of water samples from groundwater wells contained elevated As levels (Yang et al., 2009). In addition to pyrite that contained up to $1944 \mathrm{mg} / \mathrm{kg}$ of As in low grade metamorphic rocks of Waterville Formation with a mean As concentration of $47.4 \mathrm{mg} \mathrm{kg}^{-1}$, other non-sulfide mineral hosts for As are most likely in higher grade metamorphic rocks that have a mean As of $10.8 \mathrm{mg} \mathrm{kg}^{-1}$ ( $p=0.012$ ) (O'Shea et al., 2015-in this issue). That metamorphism associated with high As concentration in rocks is also observed in southwest Vermont, where the whole-rock As content is inversely related to metamorphic grade, ranging from a mean of $26.9 \mathrm{mg} \mathrm{kg}^{-1}$ in low-grade black shales and slates to $13.8 \mathrm{mg} \mathrm{kg}^{-1}$ in higher-grade black phyllites $(p<0.03$ ) (Ryan et al., 2015-in this issue). On the basis of a positive correlation between $\delta^{34} \mathrm{~S}$ and arsenic content in the pyrite in slates and phyllites from southwest Vermont, it is hypothesized that an increasing amount of arsenic was incorporated into pyrite as the marine sediment became more reducing; hence, the origin of arsenic is sedimentary for these low grade metamorphic rocks (Mango and Ryan, 2015-in this issue). Both O'Shea et al. (2015in this issue) and Mango and Ryan (2015-in this issue) observed that with increasing degrees of metamorphism, As concentrations in pyrite were lowered, possibly through a desulfidation reaction. Although further investigation is needed, the concentration of As in the original protoliths appears to be a factor contributing to As in groundwater. For example, in the Gettysburg Basin 18\%-39\% of rock samples have arsenic concentrations greater than the crustal average of $2 \mathrm{mg} / \mathrm{kg}$, whereas in the Newark Basin concentrations in $73 \%$ to $95 \%$ of rock samples are above the crustal average (Blake and Peters, 2015-in this issue). Correspondingly, 8-39\% of groundwater samples from the Gettysburg Basin contain above $10 \mu \mathrm{g} / \mathrm{L}$ of As, compared to $24-54 \%$ of ground water samples from the Newark Basin. It is also evident that the maximum concentrations of As observed in rocks from these regions with elevated groundwater As (Table 1) are many orders of magnitude greater than the upper crust abundance of As of $4.8 \mathrm{mg} / \mathrm{kg}$ (Rudnick and Gao, 2003). It should be pointed out, however, that the variations in As concentrations in marine sediment protoliths are substantial because of grain size and oxic versus anoxic depositional environment and that hydrothermal fluid migration during metamorphism can further alter the As distribution in the meta-sedimentary rock formations in the northeastern United States and Atlantic Canada (Table 1).

Relevant to risk assessment is the degree of temporal variability of private well water As, a topic not as well understood as the heterogeneous spatial distributions of well water As. Concern for temporal and spatial variability is perhaps why governmental agencies in the U.S. recommend that well owners regularly test their well water, although the recommended interval for testing varies (Table 2). Like studies of temporal variability conducted elsewhere, the degree of variability in arsenic concentration is usually low enough compared to measurement uncertainties such that a single measurement is generally representative. In central Maine, no significant difference was found when arsenic concentrations were compared for the 36 private wells sampled in 2006 and 2007 (Yang et al., 2012) and 25 private wells sampled in 2006, 2007, and 2010 and again in 2013 (Flanagan et al., 2015-in this issue); and the $\mathrm{pH}$, dissolved oxygen, and major ion concentrations were also comparable. In this special issue, evaluation of temporal data of arsenic concentrations compiled for 1245 public and private drinking water wells mostly from New England has found that increases or decreases in concentrations of arsenic $> \pm 4 \mu \mathrm{g} / \mathrm{L}$ were observed for about $11 \%$ of all wells ( $\mathrm{n}=1,245)$ and for about $17 \%$ of a subset of wells with measurable (generally $>1 \mu \mathrm{g} / \mathrm{L}$ ) concentrations of As $(\mathrm{n}=681$ ) (Ayotte et al., 2015-in this issue). It is worth noting that the concentrations of As from all private wells $(n=183)$ are less variable than those from public wells $(n=161)$, suggesting that the frequency of regular monitoring recommended for private wells by government agencies is likely to be sufficient for most wells, with a caveat that water usage or pumping rates do not vary a great deal for individual households. This caveat is because studies, including Yang et al. (2015-in this issue), found that total (un-filtered and acidified) As concentrations in well water varied considerably when the borehole was pumped over several hours, although the dissolved (filtered and acidified) As concentrations in well water varied little (Bottomley, 1984; Yang et al., 2015-in this issue). Both studies suggest that As sorbed to Fe precipitates in a borehole can account for differences in total and dissolved well water As concentrations during pumping, with Yang et al. (2015-in this issue) proposing a conceptual model invoking sorption control of As onto secondary Fe minerals along a groundwater flow path following an oxic-suboxic(-anoxic)-suboxic-oxic gradient from "recharge" to "discharge" into the borehole as a plausible mechanism.

\section{Impediments to arsenic risk reduction}

Because As in water is tasteless and odorless, it is not possible for consumers to recognize this hazard without testing. The lack of a perceived problem by private well owners in Ontario, Canada, was found to be a significant barrier for regularly testing well water for bacteria (Imgrund et al., 2011). Generally, aesthetics informs the perception people have regarding water quality. This is consistent with "optimistic bias" in public perception of environmental risks, whereby people perceive that most pollution is caused by a specific polluter and it is the government's responsibility to mitigate. This understanding was established through a series of studies on home radon ( $\mathrm{Rn}$ ) testing behaviors. Studies in New Jersey have shown that people who did not test for Rn tended to believe that they were less at risk than their neighbors (Weinstein et al., 1988). This led the authors to suggest that efforts to encourage health-protective behavior for naturally occurring environmental hazards can benefit from acknowledgment of the prevalence of such optimistic tendencies-the "precaution adoption process" model (Sandman and Weinstein, 1993; Weinstein and Sandman, 1992).

Although home Rn and well water As are similar in that they are (1) geologically sourced human-health hazards occurring in private homes and (2) the homeowners' responsibility to test and to mitigate, questions remain as to what extent the aforementioned understanding of home Rn testing is applicable to well water As testing. One difference is that mitigation for As can be more costly than mitigation for Rn and requires regular monitoring of treated water to ensure safety. Studies of safe water consumption behavior have found that risk perception is also a weak predictor of health behavior change and that additional factors, such as attitudes, social norms, or self-regulation, may be influential. Severtson et al. (2006) applied health behavior theory related to psychological processing to help understand how people responded to information about As-contaminated well water and found that specific well testing information may be incongruent with optimistic beliefs about drinking water quality; about half of the surveyed private well users in Wisconsin with As levels exceeding the MCL were not taking any action to reduce As exposure (Severtson et al., 2006). In rural Bangladesh, other psychological-theory-based studies used the RANAS model (Risk, Attitude, Norm, Ability, and Self-Regulation) (Mosler, 
2012) to assess the behavioral determinants behind the use of water sources and found that the strongest predictors of the use of neighboring As-safe tube wells were high commitment, strong descriptive norms, and high self-efficacies (Inauen et al., 2013).

The aforementioned precaution adoption process model of Weinstein and Sandman (1992) was also applied to understand the level and types of precautionary actions designed to protect children against the health effects of drinking water contaminants taken by low-income families relying on private wells (Postma et al., 2011). Households ( $\mathrm{n}=188$ ) with income levels 2.5 times lower than the federal poverty level and with at least one child under the age of 7 in Gallatin County, Montana, and Whatcom County, Washington, were studied. Most families had never tested their well water and many had never thought about taking precautions. Results suggest that young families with low incomes and low levels of education, as well as renters, are the least likely to have ever tested their well water. Subsequent water testing results of these households highlight the need for testing because about $27 \%$ of homes had at least one contaminant present in their water at levels above a EPA MCL. In order of frequency, contaminant results greater than human-health benchmarks included total coliforms (18\%), arsenic (6\%), synthetic organic chemicals (6\%), nitrates (2\%), fluoride (2\%) and Escherichia coli $(<1 \%)$.

In this special issue, a questionnaire survey $(n=420)$ and interview $(\mathrm{n}=32)$ study designed to identify gaps in public risk knowledge regarding arsenic risk exposure in private wells in Nova Scotia (Chappells et al., 2015-in this issue) found that the majority of respondents (60\%) reported having "no" or "low" concern about the health risks of arsenic in their well water. Structured interviews found that the top reasons for not testing were a lack of concern (42\%), inconvenience (23\%), and cost of testing (16\%). Optimistic biases were evident in the structured interview. Over half of the interviewees reported that they knew that high concentrations of As were a concern in Nova Scotia but did not identify this as a risk at a local level. Several had heard of neighbors experiencing problems with As, but this was rarely regarded as a personal threat to their own health even if they resided in an area where elevated arsenic levels had been found nearby. Likewise, similar optimistic biases were found in a mailed survey of randomly selected households $(n=452$ ) conducted in January 2013 in 13 towns of Central Maine, an area with high well-water dependency and frequent natural groundwater As (Flanagan et al., 2015-in this issue). The survey applied the RANAS model (Mosler, 2012) and found that having knowledge that chronic exposure increases Asrelated health risks (risk knowledge), knowing who to contact to test well water (action knowledge), believing that regular testing does not take too much time (instrumental attitude), and having neighbors who regularly test their water (descriptive norm) are significant predictors of testing for As. Accepting the prevalence of optimistic bias, Flanagan et al. (b), conclude that as long as private well testing and treatment are left up to the owners, there will always be population exposure to As through consumption of well water.

The health protective action taken by well owners, once they have tested their well water and found concentrations of As above the EPA MCL, is either to install a treatment system or to switch to drinking bottled water. Only a few studies examined the technical performance of household As treatment systems in real-world situations; the findings are concerning and the reasons for treated water still being noncompliant with MCL are not well understood because they could be technical or maintenance related. Spayd et al. (2015-in this issue) provide preliminary evidence for the relatively more effective reduction of As exposure through a point-of-entry (POE) or whole house treatment system using granular ferric oxide media, a media that has been found to perform better than reverse osmosis (Pratson et al., 2010). A decision on which mitigation option to use is not simple because cost and maintenance requirements differ (Sargent-Michaud et al., 2006). Drinking bottled water requires no maintenance but is expensive for most households; using a point-of-use (POU) system requires relatively little maintenance and relatively low expense but suffers high failure rates due to ineffective removal of As(III) by reverse osmosis (Walker et al., 2008); installing a POE system requires a relatively large capital investment and high maintenance costs. In this special issue, Flanagan et al. (b), report on a follow-up survey in Jan 2013 of households that had been mailed water-quality test results revealing As $>10 \mu \mathrm{g} / \mathrm{L}$ between 2006 and 2010 in central Maine after they voluntarily participated in a free water testing program offered by Columbia University. Of the 256 households that responded, $43 \%$ installed or use some kind of water treatment system for As, $30 \%$ drink bottled water or from another source such as a neighbor's As-safe well, and $27 \%$ took no action in response to the arsenic test results. The concentration of As in well water appears to be a factor for mitigation: $31 \%$ of households with well water As concentrations between 10 and $50 \mu \mathrm{g} / \mathrm{L}(\mathrm{n}=201)$ did not act, compared to $11 \%$ of households with well water As concentrations $>50 \mu \mathrm{g} / \mathrm{L}(\mathrm{n}=55)$. Belief that untreated water is not safe to drink (risk) and that reducing drinking water As would increase home value (instrumental attitude) were identified as significant predictors of mitigating As. A majority of households (72\%) agreed it costs a lot of money to decrease As exposure. Being "not concerned" about the As level was also common among those given results between 10 and $50 \mu \mathrm{g} / \mathrm{L}$ and who decided not to act. There are indications that households can benefit from guidance on treatment options: $48 \%$ agreed that "It is difficult to compare the pros and cons of As control methods," and $24 \%$ were not confident they could maintain a treatment system.

\section{Moving towards solutions}

There are indeed many technical and human behavioral challenges in the reduction of As exposure in the population of private well users. However, it is worth noting that public health gains often take many decades to attain after a hazard is recognized, and these gains can be fraught with setbacks. In light of this, the As hazard in private well water is similar to other challenging public health problems. We now know that statistical models used to predict the likelihood of regional As occurrence are imperfect; however, combined with existing testing data, they can be useful to guide efforts for screening. Until models can predict with better accuracy and with lower error than current models, predicting concentrations of arsenic in private wells will remain a regional-scale tool. New statistical models that utilize classification tree methods and (or) bootstrapping techniques, as well as models designed to make use of output from other, more complex models of hydrologic information, such as output from groundwater flow models, may help to improve predictions (Nolan et al., 2014).

We also know that the typical doses of As from private well water of northeastern America are low to moderate and that the detrimental health impact of As may be most severe for fetuses and young children (Naujokas et al., 2013). Therefore, it may be warranted to integrate public health campaigns on As testing and treatment with intervention programs that intend to reach pregnant women and families with young children. Such integrated approaches have been applied to exposure to lead-based paint and mercury in fish. To this end, it is encouraging that the American Academy of Pediatrics (AAP) has issued a policy statement recommending that pediatric health care providers ask families whether they drink water from a well at home (Rogan et al., 2009). AAP also recommends regular biologic and chemical testing of private wells that supply drinking water to the U.S. children, including testing for As. Because some studies suggest that this is an environmental justice issue affecting the low income, less educated, rural populations in the U.S., targeting vulnerable populations might be warranted. The AAP's policy statement recommends "Tests determined to be necessary for the safety and health of the families' drinking well water should be convenient and, if possible, free or inexpensive." We suggest that such a policy might benefit private well owners in New England and beyond. Because current regulations adopted by some states (Table 2) rely on real estate transactions or new well installations to trigger testing, 
these safeguards are unlikely to reach the low income families who are most likely to be renters. Additionally, such families will need additional support to reduce exposure after testing. Sustained public resources, devoted to private well users, especially low income families with young children, are one way to improve drinking water safety. In terms of impact, consider a hypothetical town with 1000 households using private wells and with a $20 \%$ As occurrence rate (Fig. 2). Even after $50 \%$ of the households have tested their well water for As, and even after $70 \%$ of those tested have taken actions to either avoid As through drinking bottled water or to treat for As, there remain 137 households exposed to $>10 \mu \mathrm{g} / \mathrm{L}$ of As. This can be due to households being unaware of As because they have not tested for it $(\mathrm{n}=100)$, to their testing for As but not taking action $(\mathrm{n}=30)$, or to their taking action but their treatment units are failing $(\mathrm{n}=7)$.

Considering all of the impediments to testing and treating, does it still make sense to drill wells into rock formations where we know that there is a high likelihood of encountering unsafe levels of arsenic? There is no easy answer to this question, yet consideration of alternative water sources has not been a major part of the dialogue on reducing exposure, largely because of the perception that bedrock aquifers are the best choice for private water supply. We suggest that treatment of already contaminated wells may not be the only way to reduce exposure and that developing alternative water sources for private wells where arsenic is not typically found would immediately reduce exposure and would require no maintenance of an arsenic treatment system. There are many potential ways to develop alternative sources of water supply that can be considered, including connecting to a public supply source where feasible; developing small, localized, public community water supplies that would fall under the jurisdiction of the Safe Drinking Water Act; or developing alternative shallow-well designs, which are bacteria and drought resistant, in the glacial-deposit aquifers that overlie the bedrock aquifer.

In the latter case, for example, it is generally true that water from wells in glacial aquifer materials have either slightly acidic $\mathrm{pH}$ or are oxic. In these conditions As will not be mobilized to the same extent as in wells in the underlying bedrock, which often are slightly alkaline and anoxic. The glacial aquifer has been overlooked recently due to the concern that the water is often bacteriologically unsafe and that the aquifer does not produce water of sufficient quantities to be useful. Whereas this has been true historically, it may be due in part to deficient well designs. Traditional designs call for excavating a large hole and installing a stack of approximately 1-m-diameter concrete well tiles (casing), with a concrete cap. These installations can become compromised and permit the entry of bacteria from runoff, precipitation, and entry of insects and rodents. New, alternative designs for glacial aquifer wells (dug wells) can prevent these conditions from occurring and may warrant consideration and testing (Ayotte, 2014). Although such wells would not replace all drilled wells, they may have a place in the plan to reduce exposure to arsenic for the domestic well population.

There is a long way to go to eliminate exposure to As through drinking water from private wells. It has been suggested that a more appropriate and scientific approach to private well oversight in New England be developed through more regional coordination (Tramposch, 2008). At this crossroads in our understanding of arsenic concentrations in northeastern well waters, and the goal of reducing arsenic exposure, we suggest that the development of an exposurereduction tool box could be a viable way forward. This tool box could include the best-available guidance on testing, treating, using alternative water sources, and reducing one's As exposure in other ways, including consideration of food-borne sources of As. The potential for As to occur in wells will always be with us, and therefore the development of a strategy to reduce exposure will be ongoing. Thus, thoughtful consideration of the range of options to reduce exposure in areas prone to having wells with high levels of arsenic, including efforts to encourage testing, treatment, alternative water sources, and regulation of private wellwater quality, may be warranted at local, state, and regional levels. Some regulations have already been implemented at the state and local levels (Table 2). We are at the crossroads where As in private well water of this region is recognized as a public health issue. It is best to address the issue head on.

\section{Acknowledgment}

This paper benefited from partial support by the U.S. National Institute of Environmental Health Sciences Superfund Research Program 3 P42 ES10349 to YZ. We thank all of the authors who contributed papers to this special issue. We also thank Qiang Yang, Sara V. Flanagan, and Keith Robinson for the helpful discussions related to this paper. This is LDEO contribution 7842 .

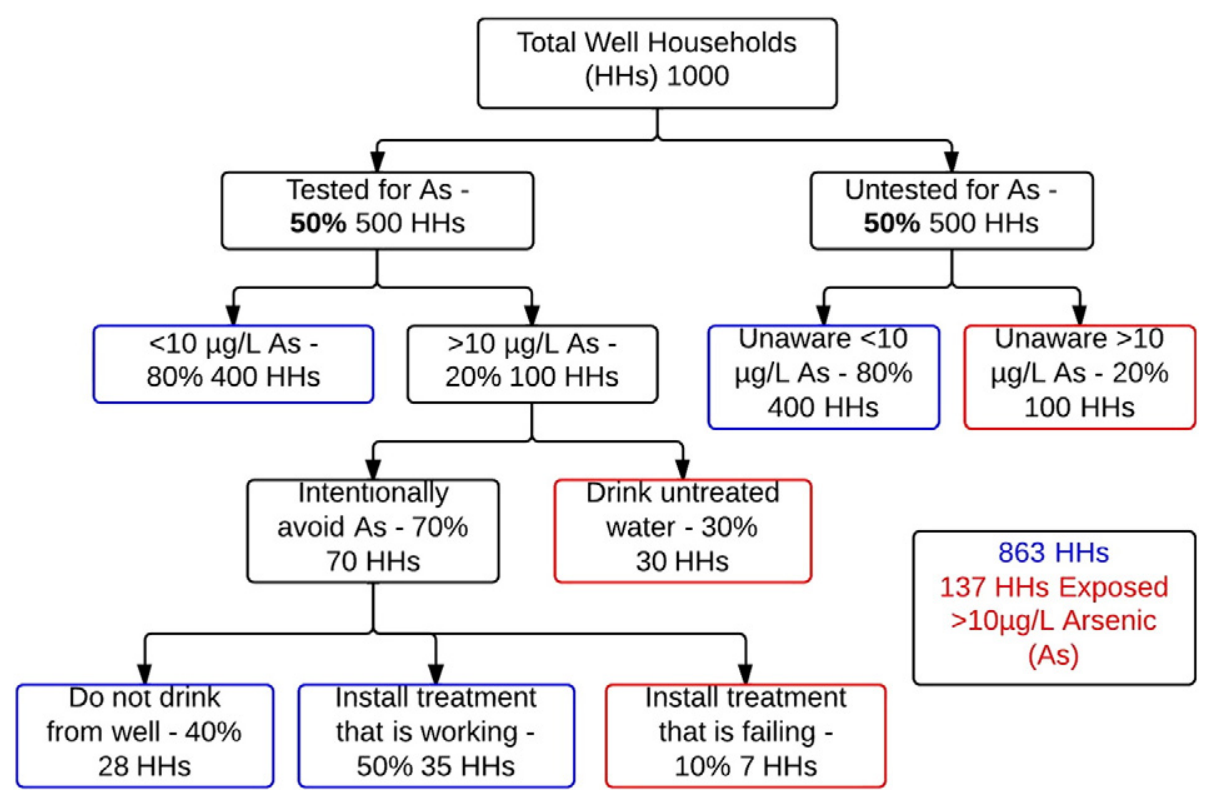

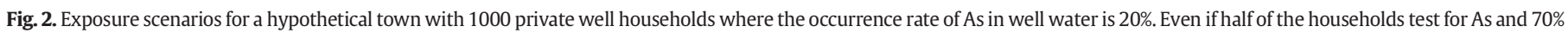
of the tested households take action to avoid or to treat As, 137 households would still be exposed to As out of the 200 households at risk of exposure. 


\section{References}

Ayotte, JD. Safe, directional, drought-resistant dug well (SSDW), US patent application 14/ 488,097, September 16, 2014.

Ayotte JD. Arsenic hazard in groundwater and associated health risks: New England, U.S. A. In: Bhattacharya P, Jovanovic D, Polya DA, editors. London: IWA Publishing; 2014s. [in press].

Ayotte JD, Nielsen MG, Robinson Jr GR, Moore RB. Relation of arsenic, iron, and manganese in ground water to aquifer type, bedrock lithogeochemistry, and land use in the New England coastal basins. US Geol Surv 1999:30.

Ayotte JD, Montgomery DL, Flanagan SM, Robinson KW. Arsenic in groundwater in eastern New England: Occurrence, controls, and human health implications. Environ Sci Technol 2003;37:2075-83.

Ayotte JD, Nolan BT, Nucklos JR, Cantor KP, Robinson GR, Baris D, et al. Modeling the probability of arsenic in groundwater in New England as a tool for exposure assessment. Environ Sci Technol 2006;40:3578-85.

Ayotte JD, Belaval M, Olson SA, Burow KR, Flanagan SM, Hinkle SR, et al. Factors affecting temporal variability of arsenic in groundwater used for drinking water supply in the United States. Sci Total Environ 2015:1370-9. [in this issue].

Ayuso RA, Foley NK. Anthropogenic and natural lead isotopes in Fe-hydroxides and Fesulphates in a watershed associated with arsenic-enriched groundwater, Maine, USA. Geochemistry- Explor Environ Anal 2008;8:77-89.

Blake JM, Peters SC. The occurrence and dominant controls on arsenic in the Newark and Gettysburg Basins. Sci Total Environ 2015:1340-9. [in this issue].

Bottomley DJ. Origins of some arseniferous groundwaters in Nova Scotia and New Brunswick, Canada. J Hydrol 1984;69:223-57.

Boudette EL, Canney FC, Cotton JE, Davis RI, Ficklin WH, Motooka JM. High levels of arsenic in the ground waters of southeastern New Hampshire-a geochemical reconnaissance. US Geol Surv 1985:20.

Brooks RR, Fergusson JE, Holzbecher J, Ryan DE, Zhang HF. Pollution by arsenic in a goldmining district in Nova Scotia. Environ Pollut B Chem Phys 1982;4:109-17.

Brown CJ, Chute SK. Arsenic concentrations in bedrock wells in Colchester, East Hampton and Woodstock, Connecticut. US Geol Surv 2002:23.

Chappells H, Campbell N, Drage J, Fernandez CV, Parker L, Dummer TJB. Understanding the translation of scientific knowledge about arsenic risk exposure among private well water users in Nova Scotia. Sci Total Environ 2015:1259-73. [in this issue].

Colman JA. Arsenic and uranium in water from private wells completed in bedrock of east-central Massachusetts: concentrations, correlations with bedrock units, and estimated probability maps. US Geol Surv 2011:113.

DeSimone LA, Hamilton PA, Gilliom RJ. Quality of ground water from private domestic wells. Water Well J 2009;1:1-6.

Dummer TJB, Yu ZM, Nauta L, Murimboh JD, Parker L. Geostatistical modelling of arsenic in drinking water wells and related toenail arsenic concentrations across Nova Scotia, Canada. Sci Total Environ 2015:1248-58. [in this issue].

Flanagan SM, Ayotte JD, Robinson Jr GR. Quality of water from crystalline rock aquifers in New England, New Jersey, and New York, 1995-2007. US Geol Surv 2012:104.

Flanagan SM, Belaval M, Ayotte JD. Arsenic, iron, lead, manganese, and uranium concentrations in private bedrock wells in southeastern New Hampshire, 2012-2013. US Geol Surv 2014:6 http://dx.doi.org/10.3133/fs20143042.

Flanagan SV, Marvinney RG, Johnston RA, Yang Q Zheng Y. Dissemination of well water arsenic results to homeowners in Central Maine: influences on mitigation behavior and continued risks for exposure. Sci Total Environ 2015:1282-90. [in this issue-a].

Flanagan SV, Marvinney RG, Zheng Y. Influences on domestic well water testing behavior in a Central Maine area with frequent groundwater arsenic occurrence. Sci Total Environ 2015:1274-81. [in this issue-b].

Grantham DA, Jones JF. Arsenic contamination of water wells in Nova Scotia. J Am Water Works Assoc 1977;69:653-7.

Gross EL, Low DJ. Arsenic concentrations, related environmental factors, and the predicted probability of elevated arsenic in groundwater in Pennsylvania. US Geol Surv 2013: 56.

Hutcheson MS, Dupuy CJ, Matyas B, McGeorge L, Vanderslice R. Reconciling science and policy in setting federal drinking-water standards: four states' perspectives. Regul Toxicol Pharmacol 1995;22:11-23.

Hutson SS, Barber NL, Kenney JF, Linsey KS, Lumia DS, Maupin MA. Estimated use of water in the United States in 2000. US Geol Surv 2004:46.

Imgrund $\mathrm{K}$, Kreutzwiser R, de Loe R. Influences on the water testing behaviors of private well owners. J Water Health 2011;9:241-52

Inauen J, Tobias R, Mosler H-J. Predicting water consumption habits for seven arsenic-safe water options in Bangladesh. BMC Public Health 2013;13:417-27.

Klassen RA, Douma SL, Ford A, Rencz A, Grunsky E. Geoscience modelling of relative variation in natural arsenic hazard potential in New Brunswick. Current Research. Geol Surv Can 2009:9.

Lipfert Gail Elizabeth. A geochemical, isotopic, and petrologic study of a watershed with arsenic-enriched ground water in Northport, Maine. Diss. University of Maine; 2006.

Lipfert G, Reeve AS, Sidle WC, Marvinney R. Geochemical patterns of arsenic-enriched ground water in fractured, crystalline bedrock, Northport, Maine, USA. Appl Geochem 2006;21:528-45.

Mango H, Ryan P. Source of arsenic-bearing pyrite in southwestern Vermont, USA: sulfur isotope evidence. Sci Total Environ 2015:1331-9. [in this issue].

Marvinney RG, Loiselle MC, Hopeck JT, Braley D, Krueger JA. Arsenic in Maine groundwater: an example from Buxton, Maine. Focus Conference on Eastern Regional Ground Water Issues. Burlington, VT: National Ground Water Association; 1994. p. 701-15.

Meranger JC, Subramanian KS, McCurdy RF. Arsenic in Nova Scotian groundwater. Sci Total Environ 1984;39:49-55.
Moore RB. Quality of water in the fractured-bedrock aquifer of New Hampshire. U.S. Geological Survey; 2004. p. 30.

Mosler H-J. A systematic approach to behavior change interventions for the water and sanitation sector in developing countries: a conceptual model, a review, and a guideline. Int J Environ Health Res 2012;22:431-49.

Mumford A, Barringer J, Reilly P, Eberl D, Blum A, Young L. Biogeochemical environments of streambed-sediment pore waters with and without arsenic enrichment in a sedimentary rock terrain, New Jersey Piedmont, USA. Sci Total Environ 2015: 1350-60. [in this issue].

Naujokas MF, Anderson B, Ahsan H, Aposhian HV, Graziano JH, Thompson C, et al. The broad scope of health effects from chronic arsenic exposure: update on a worldwide public health problem. Environ Health Perspect 2013;121:295-302.

Nielsen MG, Lombard PJ, Schalk LF. Assessment of arsenic concentrations in domestic well water, by town, in Maine, 2005-2009. US Geol Surv 2010:68.

Nolan BT, Gronberg JM, Faunt CC, Eberts SM, Belitz K. Modeling nitrate at domestic and public-supply well depths in the Central Valley. Calif Environ Sci Technol 2014; 48(10):5643-51.

NRC. Critical aspects of EPA's IRIS assessment of inorganic arsenic: interim report. Washington, D.C.: The National Academies Press; 2013

O'Shea B, Stransky M, Leitheiser S, Brock P, Marvinney RG, Zheng Y. Heterogeneous arsenic enrichment in meta-sedimentary rocks in central Maine, United States. Sci Total Environ 2015:1308-19. [in this issue].

Peters SC. Arsenic in groundwaters in the Northern Appalachian Mountain belt: a review of patterns and processes. J. Contam Hydrol 2008;99:8-21.

Peters SC, Blum JD. The source and transport of arsenic in a bedrock aquifer, New Hampshire, USA. Appl Geochem 2003;18:1773-87.

Peters SC, Burkert L. The occurrence and geochemistry of arsenic in groundwaters of the Newark basin of Pennsylvania. Appl Geochem 2008;23:85-98.

Peters SC, Blum JD, Klaue B, Karagas MR. Arsenic occurrence in New Hampshire drinking water. Environ Sci Technol 1999;33:1328-33.

Peters SC, Blum JD, Karagas MR, Chamberlain CP, Sjostrom DJ. Sources and exposure of the New Hampshire population to arsenic in public and private drinking water supplies. Chem Geol 2006;228:72-84.

Postma J, Butterfield PW, Odom-Maryon T, Hill W, Butterfield PG. Rural children's exposure to well water contaminants: implications in light of the American Academy of Pediatrics' recent policy statement. J Am Acad Nurse Pract 2011;23:258-65.

Pratson E, Vengosh A, Dwyer G, Pratson L, Klein E. The effectiveness of arsenic remediation from groundwater in a private home. Ground Water Monit Remediat 2010;30: 87-93.

Ravenscroft P, Brammer H, Richards K. Arsenic pollution: a global synthesis. Oxford: JohnWiley \& Sons; 2009

Robinson Jr GR, Kapo KE. Generalized lithology and lithogeochemical character of nearsurface bedrock in the New England region. US Geol Surv 2003:60.

Rogan WJ, Brady MT, Committee on Environmental Health, Committee of Infectious Diseases. Drinking water from private wells and risks to children. Pediatrics 2009; 123:1599-605.

Rudnick RL, Gao S. Composition of the continental crust. In: Rudnick RL, editor. The crust In: Holland HD, Turekian KK, editors. Treatise on GeochemistryOxford: ElsevierPergamon; 2003. p. 1-64.

Ryan PC, Kim J, Wall AJ, Moen JC, Corenthal LG, Chow DR, et al. Ultramafic-derived arsenic in a fractured bedrock aquifer. Appl Geochem 2011;26:444-57.

Ryan PC, Kim JJ, Mango H, Hattori K, Thompson A. Arsenic in a fractured slate aquifer system, New England, USA: influence of bedrock geochemistry, groundwater flow paths, redox and ion exchange. Appl Geochem 2013;39:181-92.

Ryan PC, West DP, Hattori K, Studwell S, Allen DN, Kim J. The influence of metamorphic grade on arsenic in metasedimentary bedrock aquifers: a case study from Western New England, USA. Sci Total Environ 2015:1320-30. [in this issue].

Ryker SJ. Mapping arsenic in groundwater: a real need, but a hard problem-why was the map created? Geotimes 2001;46:34-6.

Sandman PM, Weinstein ND. Predictors of home radon testing and implications for testing promotion programs. Health Educ Q 1993;20:471-87.

Sargent-Michaud J, Boyle KJ, Smith AE. Cost effective arsenic reductions in private well water in Maine. J Am Water Resour Assoc 2006;42:1237-45.

Serfes ME, Spayd SE, Herman GC. Arsenic occurrence, sources, mobilization, and transport in groundwater in the Newark Basin of New Jersey. In: Oday PA, Vlassopoulos D, Meng Z, Benning LG, editors. Advances in arsenic research: Integration of experimental and observational studies and implications for mitigation. Washington, D.C.: American Chemical Society; 2005. p. 175-90.

Severtson DJ, Baumann LC, Brown RL. Applying a health behavior theory to explore the influence of information and experience on arsenic risk representations, policy beliefs, and protective behavior. Risk Anal 2006;26:353-68.

Shaw WD, Walker M, Benson M. Treating and drinking well water in the presence of health risks from arsenic contamination: results from a US hot spot. Risk Anal 2005;25:1531-43

Spayd SE, Robson MG, Buckley BT. Whole-house arsenic water treatment provided more effective arsenic exposure reduction than point-of-use water treatment at New Jersey homes with arsenic in well water. Sci Total Environ 2015:1361-9. [in this issue].

Tramposch K. Downgradient of New Jersey's Private Well Testing Act: regional advances in public health and groundwater planning. 2008 National Ground Water Association Conference Eastern Regional Ground Water Issues, Ronkonkoma, New York; 2008.

Utsunomiya S, Peters SC, Blum JD, Ewing RC. Nanoscale mineralogy of arsenic in a region of New Hampshire with elevated As-concentrations in the groundwater. Am Mineral 2003;88:1844-52.

Walker M, Seiler RL, Meinert M. Effectiveness of household reverse-osmosis systems in a Western US region with high arsenic in groundwater. Sci Total Environ 2008;389: 245-52. 
Weinstein ND, Sandman PM. A model of the precaution adoption process: evidence from home radon testing. Health Psychol 1992;11:170-80.

Weinstein ND, Klotz ML, Sandman PM. Optimistic biases in public perceptions of the risk from radon. Am J Public Health 1988;78:796-800.

Yang Q Jung HB, Culbertson CW, Marvinney RG, Loiselle MC, Locke DB, et al. Spatial pattern of groundwater arsenic occurrence and association with bedrock geology in Greater Augusta, Maine. Environ Sci Technol 2009;43:2714-9.
Yang Q Jung HB, Marvinney RG, Culbertson CW, Zheng Y. Can arsenic occurrence rates in bedrock aquifers be predicted? Environ Sci Technol 2012;46:2080-7.

Yang Q Culbertson CW, Nielsen MG, Schalk CW, Johnson CD, Marvinney RG, et al. Flow and sorption controls of groundwater arsenic in individual boreholes from bedrock aquifers in central Maine, USA. Sci Total Environ 2015:1291-307. [in this issue].

Zuena AJ, Keane NW. Arsenic contamination of private potable wells. Proceedings of ASCE Specialty Conference, Environmental Engineering, Boston, July 1-5; 1985. 